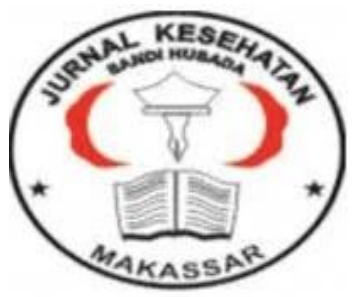

\author{
Jurnal Ilmiah Kesehatan Sandi Husada \\ hhttps://akper-sandikarsa.e-journal.id/JIKSH \\ Volume 9, Nomor 2, Desember 2020, pp 996-1002 \\ p-ISSN: 2354-6093 dan e-ISSN: 2654-4563 \\ DOI: $10.35816 /$ jiskh.v10i2.439
}

\title{
Konsumsi Kopi untuk Mencegah Penyakit Alzheimer
}

Artikel Review

Consumption of Coffee to Prevent Alzheimer's Disease

\begin{abstract}
Bimo Husodo ${ }^{1}$
1 Progam studi pendidikan dokter/Universitas Lampung

Artikel info

Artikel history:

Received; Agustus 2020

Revised;September 2020

Accepted;Oktober 2020

Abstract.

Kopi adalah salah satu minuman yang paling banyak dikonsumsi di dunia dan sebagian besar or ang dewasa minum kopi setiap hari. Kopi mengandung ratusan senyawa bioaktif, termasuk kafein, asam klorogenat, polifenol, dan sejumlah kecil mineral dan vitamin yang di antaranya diketahui memiliki efek positif bagi kesehatan otak. Penyakit Alzheimer adalah penyakit degeneratif pada otak dan penyebab paling umum dari demensia yang ditandai dengan penurunan daya ingat, bahasa, pemecahan masalah, dan keterampilan kognitif lain yang memengaruhi kemampuan seseorang untuk melakukan aktivitas sehari-hari. Tujuan dari studi literatur ini adalah untuk mengetahui manfaat konsumsi kopi untuk mencegah penyakit Alzheimer. Metode. Penelitian ini merupakan studi literatur dan sumber pustaka yang digunakan melibatkan 15 pustaka yang berasal dari 1 jurnal nasional dan 14 jurnal internasional. Hasil. Beberapa studi menunjukkan efek pencegahan dari kopi pada penyakit Alzheimer dan penurunan kognitif melalui berbagai mekanisme misalnya berperan dalam penurunan kadar A $\beta$ plasma, serta sebagai antioksidan yang dapat mengurangi peradangan dan melindungi dari demensia. Kesimpulan. Kopi dapat memberikan efek protektif pada penyakit alzheimer serta aman dikonsumsi apabila tidak melebihi dosis yang dianjurkan
\end{abstract}

\begin{abstract}
.
Coffee is one of the most consumed beverages in the world and most adults drink coffee every day. Coffee contains hundreds of bioactive compounds, including caffeine, chlorogenic acid, polyphenols, and small amounts of minerals and vitamins, which are known to have positive effects on brain health. Alzheimer's disease is a degenerative disease of the brain and the most common cause of dementia characterized by decreased memory, language, problem solving and other cognitive skills that affect a person's ability to perform daily activities. The purpose of this literature study is to determine the benefits of coffee consumption in preventing Alzheimer's disease. Method. This research is a literature study and library sources used involving 15 libraries from 1 national journal and 14 international journals. Result. Several studies have shown
\end{abstract}


the preventive effects of coffee on Alzheimer's disease and cognitive decline through various mechanisms such as a role in lowering plasma $A \beta$ levels, as well as an antioxidant that can reduce inflammation and protect against dementia. Conclusion. Coffee can have a protective effect on Alzheimer's disease and is safe to consume if it does not exceed the recommended dosage.

Keywords:

Alzheimer's disease;

Beta-amyloid;

Caffeine;
Coresponden author:

Email: husodo25@gmail.com

artikel dengan akses terbuka dibawah lisensi CC BY -4.0

\section{Pendahuluan}

Penyakit Alzheimer (AD) adalah gangguan neurodegeneratif progresif yang menjadi penyebab utama demensia di dunia (Hu et al., 2013). Demensia ditandai dengan penurunan daya ingat, kemampuan bahasa, pemecahan masalah, dan keterampilan kognitif lain yang memengaruhi kemampuan seseorang untuk melakukan aktivitas seharihari. Penurunan ini terjadi karena sel saraf (neuron) di bagian otak yang terlibat dalam fungsi kognitif telah rusak atau hancur. Pada penyakit alzheimer, kerusakan dan penghancuran neuron pada akhirnya memengaruhi bagian otak lainnya, termasuk bagian yang memungkinkan seseorang menjalankan fungsi dasar tubuh seperti berjalan dan menelan. Seseorang yang berada di tahap akhir penyakit dapat menjadi terikat di tempat tidur dan membutuhkan perawatan sepanjang waktu (Gaugler et al., 2016). Jumlah penderita alzheimer diperkirakan dapat mencapai 106,8 juta orang di seluruh dunia pada tahun 2050, oleh karena itu, penyakit ini merupakan masalah kesehatan masyarakat yang berkembang dengan beban sosial ekonomi yang utama (Hu et al., 2013)

Meskipun perkembangan penyakit alzheimer adalah proses yang multifaktorial, terdapat dua patogenesis yang telah diketahui (Sinyor et al., 2020). Akumulasi protein beta-amiloid $(\mathrm{A} \beta)$ (disebut plak beta-amiloid) di luar neuron dan akumulasi bentuk abnormal dari protein tau (disebut tau tangles) di dalam neuron adalah dua dari beberapa perubahan otak yang diyakini berkontribusi pada kerusakan dan kehancuran neuron yang menyebabkan kehilangan ingatan dan gejala Alzheimer lainnya. Akumulasi A $\beta$ diyakini mengganggu komunikasi neuron-ke-neuron di sinapsis dan berkontribusi pada kematian sel. Tau tangles memblokir pengangkutan nutrisi dan molekul penting lainnya di dalam neuron dan juga diyakini berkontribusi pada kematian sel. Otak seseorang dengan penyakit Alzheimer stadium lanjut menunjukkan adanya peradangan, penyusutan yang dramatis akibat hilangnya sel, dan serpihan-serpihan yang tersebar luas dari neuron yang mati (Gaugler et al., 2016). Meskipun terbukti bahwa kedua mekanisme ini berkontribusi pada perkembangan penyakit alzheimer, perlu dipertimbangkan adanya mekanisme lain, seperti inflamasi (Sinyor et al., 2020)

Kopi adalah salah satu minuman yang aktif secara farmakologis, yang paling banyak dikonsumsi di seluruh dunia. Karena prevalensi konsumsi kopi harian yang sangat luas, efek kesehatan yang kecil pun dapat berdampak besar pada kesehatan masyarakat. Akumulasi bukti dari studi epidemiologi terbaru menunjukkan bahwa konsumsi kopi telah dikaitkan dengan pencegahan atau penundaan penyakit degeneratif termasuk diabetes mellitus tipe 2, penyakit kardiovaskular, penyakit parkinson, penyakit Alzheimer, kematian akibat penyebab lain, dan beberapa jenis kanker. Penurunan berat badan yang moderat, peningkatan sensitivitas insulin dan berkurangnya peradangan juga berkaitan dengan konsumsi kopi secara teratur. Manfaat potensial ini telah dikaitkan sebagian 
dengan antioksidan yang ada dalam kopi. Kopi dan teh telah direkomendasikan oleh pernyataan konsensus panel ahli Amerika Serikat (AS) untuk dikonsumsi dalam jumlah yang lebih banyak (Žĩ \& Žì, 2011). Kopi mengandung lebih dari seribu molekul biokimia berbeda, yang banyak terbentuk selama proses pemanggangan. Senyawa esensial yang ditemukan dalam kopi antara lain: kafein, alkohol diterpen, asam klorogenat, dan polifenol lainnya. Kafein adalah komponen utama kopi dan kandungannya sangat bervariasi. Secangkir kopi seduh rumahan berukuran $8 \mathrm{oz}$ (150 ml) mengandung antara 120-180 mg kafein. Kafein memberikan efek utamanya sebagai antagonis reseptor adenosin yang kuat di sistem saraf pusat dan perifer, sehingga merangsang neurotransmiter eksitatorik. Efek fisiologis penting yang terkait dengan kafein antara lain stimulasi sistem saraf pusat, peningkatan laju metabolisme, diuresis, dan pada orang yang jarang mengkonsumsi kafein dapat terjadi peningkatan akut tekanan darah (Žĩ \& Žì, 2011).

Selain kafein, kopi kaya akan komponen lain yang dapat melengkapi atau bersinergi dengan tindakan kafein untuk mengurangi risiko alzheimer. Misalnya, kopi kaya akan fenol makanan seperti asam klorogenat dan asam caffeic yang merupakan antioksidan (Higdon \& Frei, 2006). Kopi juga memiliki sifat anti-inflamasi melalui senyawa yang belum teridentifikasi yang dianggap bertanggung jawab atas pengurangan risiko penyakit jantung dan beberapa jenis kanker. Karena stres oksidatif/ kerusakan oleh radikal bebas dan peradangan kronis adalah proses patofisiologi kritis pada penyakit alzheimer, kandungan antioksidan dan senyawa anti inflamasi dalam kopi yang cukup besar dapat melawan kedua proses patogenesis ini dan selanjutnya dapat mengurangi risiko penyakit alzheimer (Cao et al., 2011). Saat ini kopi merupakan minuman yang sangat digemari di Indonesia baik di segala usia, oleh karena itu tujuan dari literature review ini adalah untuk mengetahui manfaat dari konsumsi kopi sebagai pencegahan penyakit alzheimer, sehingga dapat memberikan informasi yang bermanfaat bagi masyarakat.

\section{Metode}

Metode yang digunakan adalah studi literatur yang diambil dari beberapa jurnal nasional maupun internasional dan artikel ahli yang diakses online. Metode ini berupaya meringkas pemahaman kondisi terkini mengenai suatu topik. Studi literatur ini menyajikan materi yang telah diterbitkan sebelumnya dan menganalisis suatu fakta baru Penelusuran sumber pustaka dalam artikel ini melalui database PubMed dan Google Scholar. Sumber pustaka yang digunakan dalam penyusunan melibatkan 15 pustaka yang terdiri dari 1 jurnal nasional dan 14 jurnal internasional. Pemilihan artikel sumber pustaka dilakukan dengan melakukan peninjauan pada judul, abstrak dan hasil yang membahas tentang manfaat konsumsi kopi untuk mencegah penyakit Alzheimer. Hasil studi literatur ini berupa publikasi yang relevan.

\section{Hasil Dan Pembahasan}

Penelitian yang dilakukan oleh West et al. (2019) pada sampel individu lansia dengan diabetes melitus tipe 2 (DM tipe 2), didapatkan bahwa tingkat asupan kafein yang lebih tinggi secara signifikan berkaitan dengan kinerja kognitif yang lebih baik dan volume gray matter yang lebih besar. Asupan kafein memiliki hubungan yang kecil akan tetapi signifikan dengan kognisi keseluruhan $(p=0,018)$, memori kerja / perhatian $(p=0,002)$, kategorisasi semantik $(p=0,026)$, dan fungsi eksekutif $(p=.047)$ (West et al., 2019). Hal ini juga sejalan dengan penelitian oleh eskelinen et al (2010), bahwa konsumsi kopi sebanyak 3-5 cangkir per hari memiliki $65-70 \%$ penurunan risiko demensia dan $62-64 \%$ 
penurunan risiko penyakit alzheimer dibandingkan dengan konsumsi kopi yang lebih sedikit ( $\mathrm{p} \leq$ 0,05) (Eskelinen \& Kivipelto, 2010).

Sementara itu, penelitian oleh Kim et al. (2019), menunjukkan bahwa asupan kopi seumur hidup sebanyak $\geq 2$ cangkir / hari (asupan kopi lebih tinggi) dikaitkan dengan tingkat kepositifan $A \beta$ otak yang lebih rendah pada orang dewasa tua non-demensia jika dibandingkan dengan asupan kopi $<2$ cangkir / hari. Terdapat hubungan yang signifikan antara strata asupan kopi seumur hidup ( 0 atau $<1$ cangkir / hari, $1 \leq$ dan $<2$ cangkir / hari, $2 \leq$ dan $<3$ cangkir / hari, dan $3 \leq$ cangkir / hari) dan kepositifan $A \beta(p=0,048)$. Juga terdapat kecenderungan signifikansi pada hubungan dosis-efek antara jumlah total asupan kopi seumur hidup (= durasi asupan kopi $\times$ cangkir asupan kopi / hari) dan positif $\mathrm{A} \beta$ (OR $(95 \% \mathrm{CI})=0,991(0,982-1,001) ; \mathrm{p}=0,067)$. Ketika jumlahnya meningkat, maka tingkat kepositifan $A \beta$ menurun (Kim et al., 2019). Penelitian lain yang dilakukan oleh Arendash (2010), juga menunjukkan kemampuan dari asupan moderat kafein untuk melindungi dari gangguan kognitif seperti alzheimer dan neuropatologi $A \beta$ pada tikus. Kafein dalam air minum (300 mg / L) diberikan selama 2 bulan pada tikus tua yang sudah menunjukkan karakteristik penyakit alzheimer. Setelah hampir 2 bulan pemberian kafein didapatkan bahwa kadar kafein plasma yang lebih tinggi sangat berkaitan dengan kadar $A \beta$ plasma yang lebih rendah pada tikus $(p=0,011)$ (Arendash \& Cao, 2010).

Karena kopi juga mengandung banyak konstituen selain kafein yang dapat memberikan manfaat kognitif terhadap penyakit alzheimer, Cao et al (2011) membandingkan efek kopi berkafein dan tanpa kafein dalam sitokin plasma pada tikus. Pemberian dengan kopi berkafein secara signifikan dan secara khusus meningkatkan kadar granulocyte-colony stimulating factor (GCSF), IL-10, dan IL-6 plasma. Baik larutan kafein saja (yang memberikan kadar kafein plasma tinggi) atau kopi tanpa kafein juga memberikan efek ini, yang menunjukkan bahwa kafein bersinergi dengan beberapa komponen kopi yang belum teridentifikasi untuk secara selektif meningkatkan ketiga sitokin plasma ini. Peningkatan GCSF sangat penting karena dapat meningkatkan memori kerja pada tikus alzheimer melalui tiga mekanisme (pembentukan mikroglia dari sumsum tulang, sinaptogenesis, dan neurogenesis). Kopi mungkin merupakan sumber kafein terbaik untuk mencegah alzheimer karena komponen dalam kopi yang bersinergi dengan kafein untuk meningkatkan kadar GCSF plasma yang menghasilkan berbagai tindakan terapeutik terhadap penyakit alzheimer. (Cao et al., 2011).

Kopi mengandung berbagai komponen berbeda di dalamnya, antara lain kafein, polifenol, trigonelin, niasin, kalium, diterpen, dan akrilamida. Sebagian besar peneliti memusatkan perhatian mereka pada kafein, yang diyakini bahwa kafein menunjukkan efek pelindung saraf dengan memblokir reseptor adenosin, sehingga nantinya dapat menghasilkan konsentrasi serotonin dan asetilkolin-neurotransmiter yang lebih tinggi di sistem saraf pusat (Wierzejska, 2017). Kafein atau 1,3,7-trimethylxanthine, adalah alkaloid mirip purin dengan aksi biologis yang beragam dan merupakan zat psikoaktif yang paling sering dikonsumsi di dunia. Pada konsentrasi fisiologis, kafein bertindak sebagai antagonis reseptor adenosin non-selektif. Reseptor adenosin A1, A2A, A2B dan A3 adalah reseptor berpasangan G-protein. Dengan mengurangi pensinyalan melalui reseptor adenosin, kafein memodulasi aktivitas banyak sistem neurotransmitter. Namun, efek SSP kafein tidak terbatas pada tindakannya pada reseptor adenosin. Kafein dan xantin lainnya juga dapat menghambat pensinyalan reseptor GABA, meningkatkan pelepasan kalsium intraseluler dan menghambat beberapa fosfodiesterase, meskipun konsentrasi kafein yang diperlukan untuk mencapai efek ini mungkin lebih tinggi daripada yang biasanya dicapai dengan minum kopi biasa. Kafein juga memiliki efek pleiotropik pada berbagai sistem biologis, termasuk sistem saraf pusat (SSP), sistem peredaran darah, dan sistem 
kekebalan. Selain itu, kafein dimetabolisme oleh hati menjadi tiga dimetilxantin (teobromin, teofilin, dan paraxantin) masing-masing dengan efek fisiologisnya sendiri (Carman et al., 2014). Potensi neuroprotektif kafein dalam patologi neurodegenerative juga telah dibuktikan dalam beberapa model penelitian pada tikus alzheimer. Kadar kafein plasma yang tinggi berkorelasi dengan penurunan kadar $A \beta$ plasma. Jika efek serupa dapat ditunjukkan pada manusia, plasma $\mathrm{A} \beta$ dapat menjadi penanda yang berguna untuk penelitian klinis di masa depan dengan kopi, kafein, dan penyakit Alzheimer (Cao et al., 2009; Carman et al., 2014).

Konsumsi kafein juga ditemukan dapat melindungi kerusakan neurologis dan mencegah kerusakan memori terkait DM tipe 2 pada tikus. Sehingga penggunaan kafein jangka panjang berpotensi bermanfaat dalam mengurangi neuropatologi dan kehilangan kognitif terkait DM tipe 2. Volume gray matter yang lebih besar pada subjek lansia yang memiliki asupan kafein yang lebih tinggi secara konsisten juga berhubungan dengan pengurangan kehilangan neuron seiring bertambahnya usia oleh asam klorogenat dan polifenol. Kafein juga melindungi sawar darah otak, meningkatkan pengeluaran $A \beta$ dan dengan demikian mengurangi risiko penyakit alzheimer serta penyakit parkinson. Kopi mengandung polifenol, khususnya asam klorogenat, antioksidan, yang dapat mengurangi peradangan dan melindungi dari demensia (Pelligrino et al., 2010; West et al., 2019).

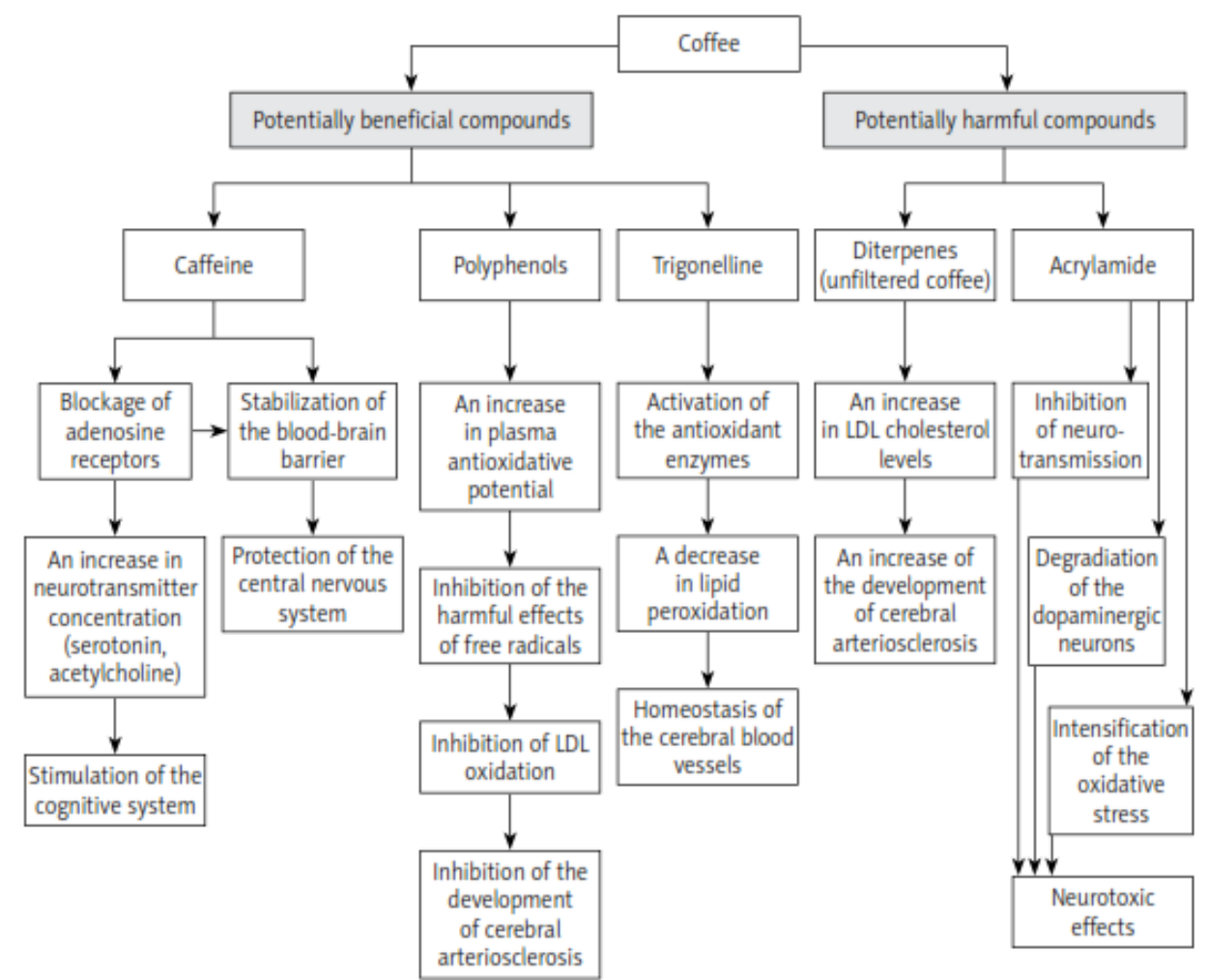

Gambar 1. Mekanisme dampak kopi terhadap risiko penyakit neurodegeneratif

(Wierzejska, 2017)

Kafein yang dikonsumsi oral dapat diserap hampir sepenuhnya melalui sistem pencernaan manusia dan masuk ke dalam sirkulasi darah dalam 1-1,5 jam. Selanjutnya kafein dalam darah akan dengan cepat mencapai keseimbangan dalam jaringan otak, karena kafein dapat secara bebas melewati sawar darah otak sehingga efisiensi kafein yang masuk ke dalam otak cukup tinggi. Efek fisiologis ataupun metabolisme kafein tidak berubah pada 
individu yang berbeda usia. Kafein diketahui dapat memberikan efek protektif pada penyakit alzheimer serta aman dikonsumsi apabila tidak melebihi dosis yang dianjurkan. Asupan kafein dengan takaran sedang, yaitu sampai dengan $400 \mathrm{mg} / \mathrm{hari}$, telah terbukti tidak memberikan efek buruk pada kesehatan orang dewasa sehat. Namun konsumsi kafein yang melebihi 500-600 mg/hari secara rutin dapat meningkatkan risiko kesehatan dan mengarah ke penyalahgunaan. Dalam dosis berlebihan, kafein dapat menyebabkan gangguan kardiovaskular, seperti aritmia dan takikardi, gangguan pencernaan seperti mual, muntah, dan diare serta dapat menganggu keseimbangan kalsium tubuh jika tidak diimbangi dengan konsumsi kalsium yang cukup (Zulkifly et al., 2017).

\section{Simpulan Dan Saran}

Kopi merupakan salah satu minuman yang paling banyak dikonsumsi baik di Indonsesia maupun di seluruh dunia. Asupan kopi dengan takaran sedang (3-4 gelas sehari), dapat menjadi strategi untuk mengurangi risiko penyakit alzheimer dan penyakit lain yang terkait dengan penuaan. Kafein dalam kopi diyakini menunjukkan efek pelindung saraf dengan memblokir reseptor adenosin, yang berpengaruh dengan penurunan kadar $A \beta$ plasma. Kafein turut melindungi sawar darah otak dengan meningkatkan pengeluaran $A \beta$ sehingga dapat mengurangi risiko penyakit alzheimer. Kopi juga mengandung polifenol, khususnya asam klorogenat, antioksidan, yang dapat mengurangi peradangan dan melindungi dari demensia.

\section{Daftar Rujukan}

Arendash, G. W., \& Cao, C. (2010). Caffeine and coffee as therapeutics against Alzheimer's disease. Journal of Alzheimer's Disease, 20(SUPPL.1), 117-126. https://doi.org/10.3233/JAD-2010-091249

Cao, C., Cirrito, J. R., Lin, X., Wang, L., Verges, D. K., Dickson, A., Mamcarz, M., Zhang, C., Mori, T., Gary, W., Holtzman, D. M., \& Potter, H. (2013). Alzheimer's transgenic mice. 17(3), 681-697. https://doi.org/10.3233/JAD-2009-1071.Caffeine

Cao, C., Wang, L., Lin, X., Mamcarz, M., Zhang, C., Bai, G., Nong, J., Sussman, S., \& Arendash, G. (2011). Caffeine synergizes with another coffee component to increase plasma GCSF: Linkage to cognitive benefits in Alzheimer's mice. Journal of Alzheimer's Disease, 25(2), 323-335. https://doi.org/10.3233/JAD-2011-110110

Carman, A. J., Dacks, P. A., Lane, R. F., Shineman, D. W., \& Fillit, H. M. (2014). Current evidence for the use of coffee and caffeine to prevent age-related cognitive decline and Alzheimer's disease. Journal of Nutrition, Health and Aging, 18(4), 383-392. https://doi.org/10.1007/s12603-014-0021-7

Eskelinen, M. H., \& Kivipelto, M. (2010). Caffeine as a protective factor in dementia and Alzheimer's disease. Journal of Alzheimer's Disease, 20(SUPPL.1). https://doi.org/10.3233/JAD-2010-1404

Gaugler, J., James, B., Johnson, T., Scholz, K., \& Weuve, J. (2016). 2016 Alzheimer's disease facts and figures. Alzheimer's and Dementia, 12(4), 459-509. https://doi.org/10.1016/j.jalz.2016.03.001

Higdon, J. V., \& Frei, B. (2006). Coffee and health: A review of recent human research. Critical Reviews in Food Science and Nutrition, 46(2), 101-123. https://doi.org/10.1080/10408390500400009

Hu, N., Yu, J. T., Tan, L., Wang, Y. L., Sun, L., \& Tan, L. (2013). Nutrition and the risk of alzheimer's disease. BioMed Research International, 2013. https://doi.org/10.1155/2013/524820

Kim, J. W., Byun, M. S., Yi, D., Lee, J. H., Jeon, S. Y., Jung, G., Lee, H. N., Sohn, B. K., Lee, J. Y., Kim, Y. K., Shin, S. A., Sohn, C. H., \& Lee, D. Y. (2019). Coffee intake and decreased amyloid pathology in human brain. Translational Psychiatry, 9(1). 
https://doi.org/10.1038/s41398-019-0604-5

Pelligrino, D. A., Xu, H. L., \& Vetri, F. (2010). Caffeine and the control of cerebral hemodynamics. Journal of Alzheimer's Disease, 20(SUPPL.1), 1-16.

https://doi.org/10.3233/JAD-2010-091261

Sinyor, B., Mineo, J., \& Ochner, C. (2020). Alzheimer's Disease, Inflammation, and the Role of Antioxidants. Journal of Alzheimer's Disease Reports, 4(1), 175-183. https://doi.org/10.3233/adr-200171

West, R. K., Ravona-Springer, R., Livny, A., Heymann, A., Shahar, D., Leroith, D., Preiss, R., Zukran, R., Silverman, J. M., \& Schnaider-Beeri, M. (2019). Age modulates the association of caffeine intake with cognition and with gray matter in elderly diabetics. Journals of Gerontology - Series A Biological Sciences and Medical Sciences, 74(5), 683-688. https://doi.org/10.1093/gerona/gly090

Wierzejska, R. (2017). Can coffee consumption lower the risk of Alzheimer's disease and Parkinson's disease? A literature review. Archives of Medical Science, 13(3), 507514. https://doi.org/10.5114/aoms.2016.63599

Žĩ, Ğ., \& Žì, Ś. (2011). SCIENCE OF MEDICINE Preventive Cardiology. December, 431-438.

Zulkifly, S., Darmawan, I., \& Tambunan, V. (2017). Manfaat Kopi untuk Mencegah Penyakit Alzheimer. 44(10), 742-744. 